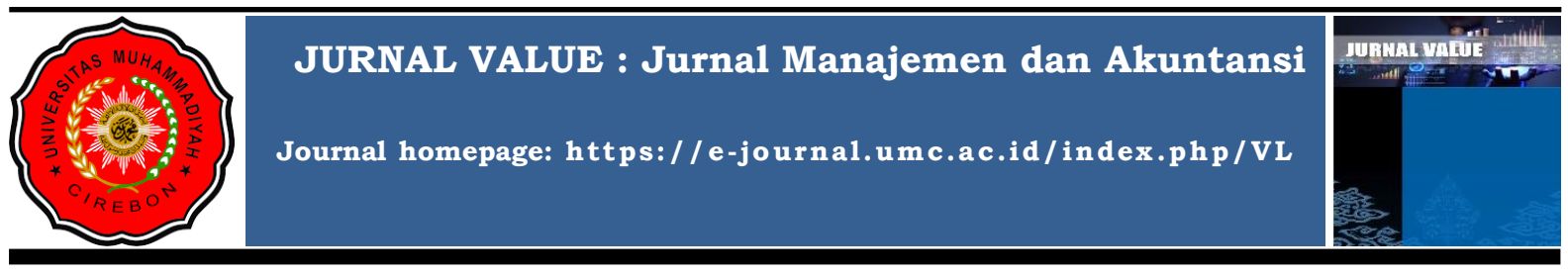

\title{
PENGARUH VISI KAMPUS TERHADAP MINAT KEANGGOTAAN ORGANISASI KEMAHASISWAAN DI UNIVERSITAS MUHADI SETIABUDI
}

\author{
Akbar Nuur Purnama Darma Wahana ${ }^{1}$ \\ Dedi Romli Triputra ${ }^{2}$ \\ Wahyu Wibowo ${ }^{3}$ \\ ${ }^{1}$ Fakultas Ekonomi dan Bisnis, Universitas Muhadi Setiabudi \\ Email : akbarnuurpurnama@gmail.com \\ ${ }^{2}$ Fakultas Keguruan dan Ilmu Pendidikan, Universitas Muhadi Setiabudi \\ Email : dediromlitriputra@gmail.com \\ ${ }^{3}$ Fakultas Ekonomi dan Bisnis, Universitas Muhadi Setiabudi \\ Email :wahyuwibowo5483@gmail.com
}

\begin{abstract}
Abstrak
Penelitian ini menganalisis pengaruh visi kampus terhadap peminatan keanggotaan Organisasi Mahasiswa di universitas Muhadi Setiabudi Brebes. Tujuan penelitian ini adalah untuk mengetahui serta menganalisis visi religius terhadap peminatan keanggotaan organisasi khususnya Lembaga dakwah kampus (LDK) di Universitas Muhadi Setiabudi. Hipotesis penelitian ini menunjukan bahwa visi religius kampus mempunyai pengaruh yang positif terhadap peminatan anggota Organisasi Mahasiswa. Metode penelitian yang digunakan pada penelitian ini yaitu metode kuantitatif deskriptif. Penentuan populasi dan sampel pada penelitian ini adalah mahasiswa universitas Muhadi Setiabudi yang berjumlah 52 mahasiswa dengan instrumen observasi dan kuesionet dengan random sampling. Teknik metode analisis data dilaksanakan dengan mengunakan metode statistik deskriptif dengan metode One-Way ANOVA, sedangkan hipotesis penelitian dilakukan pada taraf siginifikansi $\alpha=0.05$. Hasil penelitian menunjukan terdapat pengaruh yang positif dan signifikan antara visi kampus dengan minat Organisasi Kemahasiswaan. Dari nilai uji koefisien determinasi, hasil penelitian ini mencerminkan bahwa sebanyak 89,5\% varians skor minat anggota Organisasi Mahasiswa dipengaruhi oleh faktor visi kampus. Persamaan regresi yang dihasilkan untuk menunjukan pengaruh antara visi religius kampus dengan minat anggota LDK adalah $y=3.889+.895 X$, artinya setiap kenaikan satu satuan variabel visi kampus (X) akan meningkatkan variabel minat anggota Organisasi (Y) sebesar .895 pada konstanta 3.889.
\end{abstract}

Kata Kunci: Visi Kampus; Minat Organisasi Mahasiswa

\section{PENDAHULUAN}

Manusia adalah makhluk yang mampu berpikir dan mampu membawa perubahan bagi dirinya dan bagi orang banyak. Mahasiswa memiliki peran yang sangat penting baik dalam kampus maupun diluar kampus, yakni dimasyarakat. Mahasiswa diharapkan dapat mengemban tugas dengan baik sebagai agen of change, menyampaikan apa yang didapat dikampus dan menerapkannya sebagai contoh dalam kehidupan sehari-hari. Mahasiswa adalah pablik figur dimasyarakat, maka mahasiswa harus mampu menampilkan dirinya sebaik mungkin. Berbagai macam organisasi atau lembaga-lembaga yang ada dalam lingkup kampus Universitas Muhadi Setiabudi. Lembaga Dakwah kampus merupakan salah satu lembaga yang memiliki cara dan berperan penting dalam meningkatkan motivasi belajar mahasiswa. Lembaga dakwah kampus memiliki peran yang cukup besar dalam memberikan dorongan, bimbingan, arahan, agar mahasiswa selalu semangat dalam mengembangkan potensi dirinnya. Kegiatan dari suatu instansi tidak mungkin terlepas dari faktor manusia atau SDM, yang mana manusia sebagai motor penggerak jalannya suatu organisasi (Riono, 2020). Sebab hal itu, bisa disebutkan bahwa hidup serta matinya organisasi bergantung dari bagaimana cara sumber daya manusia ataupun pegawai yang tersedia dalam melaksanakan organisasi. Organisasi Lembaga dakwah kampus di Universitas Muhadi 
Setiabudi Juga organisasinya lebih menekanka ke aktifan Anggotanya dalam kegiatan Lembaga tersebut. Sebagaimana yang tercantum dalam Undang-Undang No. 20 Tahun 2003 Tentang Pendidikan Nasional: Pendidikan merupakan usaha sadar dan terencana untuk mewujudkan suasana belajar dan proses pembelajaran agar peserta didik secara aktif dapat mengembangkan potensi diri untuk memiliki kekuatan spiritual keagamaan, pengendalian diri,kepribadian, kecerdasan, akhlak mulia serta keterampilan yang diperlukan masyarakat, bangsa dan Negara (UU No. 20, 2003).

Mengingat proses dakwah dewasa ini semakin sulit dan berat, Tantangan dakwah dikalangan masyarakat dan dunia kampus juga semakin kompleks, sehingga memerlukan peranan da'i dan para jiwa muda khususnya mahasiswa sebagai komunikator serta sebagai agent of change. Dengan demikian, Lembaga Dakwah Kampus yang merupakan lembaga keagaamaan mempunyai peranan penting dalam menyalurkan dan menyampaikan pesan-pesan dakwah kepada mad'u. Agar tujuan dakwah dapat terlaksana dengan baik, maka diperlukan sebuah komunikasi yang efektif dalam melaksanakan proses dakwah agar mampu meningkatkan intensitas dakwahnya (Aisyah, 2015). Lembaga Dakwah Kampus merupakan perwujudan formal dari gerakan dakwah Islam yang dilakukan oleh para mahasiswa yang merasa peduli dengan kondisi eksistensi gerakan dilingkungan sebuah kampus. Disamping menyiarkan dakwah, lembaga dakwah juga ikut serta membentuk secara akademis proses belajar mengajar mata kuliah agama Islam (Ukbah, 2013).

Organisasi kemahasiswaan intern perguruan tinggi berfungsi sebagai sarana mahasiswa untuk menampung dan menyalurkan aspirasi mahasiswa, melalui kegiatan program kemahasiswaan. Pengembangan diri mahasiswa sebagai insan akademis, calon ilmuwan dan intelektual di masa depan, melalui pelatihan keterampilan organisasi, manajemen, dan kepemimpinan. Pembinaan (Basri, 2020). Rasa kepuasan mahasiswa yang tinggi akan memicu munculnya kreativitas dan inovasi, sehingga dosen akan memiliki sikap inisiatif yang positif dalam mengatasi permasalahan organisasi (Syaifulloh, 2017). Sehingga mahasiswa menjadi lebih produktif, karena produktivitas adalah sikap mental yang mempunyai semangat untuk melakukan peningkatan perbaikan kearah yang lebih baik lagi (Syaifulloh, Saefudin, \& Nasiruddin, 2018). Karena mengikuti Organisasi mendapatkan Manfaat lain yang dapat diperoleh mahasiswa dengan aktif pada organisasi kemahasiswaan intrakampus adalah berkembangnya kemampuan bekerja sama, ketrampilan berorganisasi serta kemampuan berkomunikasi dan ketrampilan khusus yang sesuai dengan bidang atau jenis organisasi kemahasiswaan yang diikuti (Oviyanti, 2016).

\section{KAJIAN PUSTAKA}

Organisasi kemahasiswaan merupakan wadah bagi mahasiswa untuk mengembangkan kapasitas kemahasiswaannya berupa aspirasi, inisiasi, atau gagasan-gagasan positif dan kreatif melalui berbagai kegiatan yang relafan dengan tujuan pendidikan nasional serta visi dan misi institut perguruan tinggi itu sendiri yang bekerja secara organisatori, adapun salah satu organisasi kemahasiswaan di Universitas muhadi setiabudi yang cukup diminati adalah Lembaga Dakwah Kampus Nurul Ilmi. Organisasi Kemahasiswaan adalah organisasi intra kampus yang terdapat di tiap-tiap perguruan tinggi di Indonesia. Organisasi LDK adalah oranisasi dakwah dengan syariat Islam sebagai asasnya (Pelupessy dan Husein, 2018). Sebagian besar perguruan tinggi di Indonesia pasti mempunyai LDK. Tiap-tiap perguruan tinggi memiliki nama LDK berbeda-beda. Karena Organisasi dituntut untuk berkembang sesuai dengan kondisi lingkungan sekitarnya, dan yang menjadikan organisasi berkembang adalah manusia yang melaksanakan semua tugas-tugas organisasi, baik sebagai pemimpin ataupun anggotanya (Maulana, 2010).

Peminatan peserta didik merupakan suatu proses pengambilan pilihan dan keputusan oleh peserta didik dalam bidang keahlian yang didasarkan atas pemahaman potensi diri dan peluang yang ada, Peminatan Anggota Organisasi Lembaga Dakwah kampus cukup besar peminatnya, Sehingga Proses pencarian jati diri keislaman melalui media dakwah kampus. Sehingga Massifnya budaya Barat dan Asia Timur yang menawarkan dan menampilkan kode-kode pergaulan remaja bisa di tekan dengan kegiatan kegiatan islami dan mecegah perbuatan yang negative (Kailani, 2011) karena Minat dapat direpresentasikan sebagai efek linier dan merujuk kepada faktor daya tarik yang mempengaruhi perilaku tertentu. Semakin kuat minat seseorang, maka semakin besar kemungkinan perilaku tersebut dilakukan, atau dapat dikatakan bahwa minat adalah kecenderungan spesifik individu untuk suatu tindakan atau serangkaian tindakan. Jadi penentu utama minat adalah keyakinan seseorang untuk memulai dan menjalankan sesuatu (Suasana, Suarjaya, \& Dana, 2019). 
Minat seseorang terhadap suatu objek akan lebih kelihatan apabila objek tersebut sesuai sasaran dan berkaitan dengan keinginan dan kebutuhan seseorang yang bersangkutan, dengan alasan diatas pengertian minat adalah suatu perpaduan keinginan dan kemauan yang dapat berkembang jika ada motivasi. Sedangkan dalam arti lain bahwa minat pada dasarnya merupakan penerimaan akan sesuatu hubungan antara diri sendiri dengan sesuatu di luar diri. Minat sangat besar pangaruhnya dalam mencapai prestasi dalam suatu pekerjaan, jabatan, atau karir. Tidak akan mungkin orang yang tidak berminat terhadap suatu pekerjaan dapat menyelesaikan pekerjaan tersebut dengan baik. Dari beberapa pendapat para ahli di atas dapat disimpulkan bahwa Minat merupakan kecenderungan pada seseorang yang ditandai dengan rasa senang atau ketertarikan pada objek tertentu disertai dengan adanya pemusatan perhatian kepada objek tersebut dan keinginan untuk terlibat dalam aktivitas objek tertentu, sehingga mengakibatkan seseorang memiliki keinginan untuk terlibat secara langsung dalam suatu objek atau aktivitas tertentu, karena dirasakan bermakana bagi dirinya dan ada harapan yang dituju.

Keberadaan Lembaga Dakwah Kampus di harapkan bisa menciptakan Mahasiswa memiliki akhlak mulia yang terpuji karena mahasiswa merupakan generasi penerus yang nantinya akan melanjutkan pembangunan bangsa. Untuk mendapatkan lulusan yang berkualitas mahasiswa harus memiliki akhlak mulia, sehingga kedepan dapat memimpin bangsa menjadi lebih baik yang diharapkan dapat mengubah keadaan mahasiswa menjadi lebih baik (Pelupessy dan Husein, 2018). Minimal out put yang bisa di harapkan dari Lembaga Disiplin dalam beribadah maksudnya ialah senantiasa beribadah dengan peraturan-peratuaran yang terdapat di dalamnya (Fatimah, 2014).

Lembaga Dakwah Kampus adalah lembaga yang bergerak di bidang dakwah Islam dan merupakan Oraganisasi yang melaksanakan kegiatan yang postif sehingga sivitas Akademika bisa menjauhi kegiatan yang bersifat negatif., Ditinjau dari struktur sosial kemasyarakatan, mahasiswa dan kampus merupakan satu kesatuan sistem sosial yang mempunyai peranan penting dalam perubahan sosial peri-kepemimpinan di tengah-tengah masyarakat. Mahasiswa merupakan sekelompok manusia yang memiliki taraf berpikir di atas rata-rata. Dengan demikian, kedudukan mahasiswa adalah sangat strategis dalam mengambil peran yang menentukan keadaan masyarakat di masa depan.

Menurut (Setiawan, 2011)Salah satu indikator keberhasilan lembaga dakwah kampus adalah bagaimana meningkatkan perilaku keagamaan mahasiswa yang menjadi anggota Khususnya dan seluruh Mahasiswa pada umumnya. Seperti Mahasiswa yang laki laki memakai pakaian yang sopan serta bagi wanita untuk menutup aurat, karena agama islam memiliki aturan khusus bagi wanita dalam berpakaian guna menjaga pandangan dan kehormatannya (Putri, 2017). Lembaga Dakwah Kampus (LDK) Nurul Ilmi UMUS Brebes merupakan aktualisasi para aktivis dakwah dari mahasiswa yang memiliki komitmen untuk mewujudkan kampus dengan suasana yang Islami. Dengan menanamkan nilai-nilai keislaman di lingkungan kampus serta masyarakat secara umum dengan dimensi-dimensi dakwah. Dimensi-dimensi tersebut yakni: syi'ar dan kaderisasi, pelayanan, keprofesian, dan kemasyarakatan. Aktivis LDK UMUS Senantiasa berusaha menebarkan syi'ar Islam untuk membentuk kaulitas pribadi dan umat yang robbaniyah. Secara kelembagaan LDK UMUS Brebes berada dibawah koordinasi wakil rektor III Bidang Kemahasiswaan dan Kepala Unit Pembinaan pendidikan agama (P3A).

Adapun secara umum tujuan pembinaan Lembaga Dakwah Kampus Adalah sebagai berikut;

1) Pembinaan bertujuan untuk menghidupkan hati yang mati. Misalnya seperti orang-orang yang tidak mau berusaha selalu bermalas-malasan dalam mempelajari agama Islam.

2) Agar Manusia mendapat ampunan dan menghindarkan azab dari Allah. Misalnya dengan pembinaan ini Manusia dapat menyadari kesalahannya dan dosa akan diampuni dan Allah akan menjaganya dari berbuat dosa.

3) Untuk menyembah Allah dan tidak menyekutukanNya, mengajak dan menuntun kejalan yang lurus. Dalam Pembinaan LDK inilah yang dapat menyadarkan dirinya untuk menghindari segala bentuk kemaksiatan agar ia tetap menempuh jalan yang benar.

4) Menyempurnakan hubungan Manusia dengan penciptanya (Hablum minallah), dan Manusia dengan Manusia lain (Hablum minannas).

5) Dapat menyebarkan kebaikan dan mencegah timbulnya berbagai macam kerusakan yang dapat menghancurkan dirinya, masyarakat dan bangsa maupun dunia. 
6) Membentuk individu dan masyarakat yang menjadikan Islam sebagai pegangan dan pandangan hidup dalam segala aspek kehidupan baik itu dibidang pendidikan, politik, ekonomi, sosial, budaya, maupun kesehatan.

Penelitian ini dilaksanakan karena di kampus Universitas Muhadi setiabudi yang dengan Visi Religius Kampus jumlah peminat Anggota Lembaga Dakwah kampus yang cukup besar dan karena peneliti kebutuhan rasa ingin tahu untuk meningkatkan pengetahun dan pemahaman yang lebih dalam lagi.

\section{METODE PENELITIAN}

Metode Penelitian yang di gunakan adalah penelitian Kuantitaf (Mulyanto dan Wulandari, 2010) Adapun fokus dan lokus masalah yang diselidiki oleh disiplin ilmu sosial adalah masalah-masalah sosial. 1stilah sosial menujuk pada hubungan-hubungan antara dan di antara orang-orang, kelompokkelompok (seperti keluarga), institusi (sekolah, komunitas, organisasi, dsb.). Metode pengumpulan data dengan cara Observasi Lapangan dan membagi Kuesioner kesejumlah Mahasiswa yang dijadikan sampel.

\section{Populasi dan Sampel Penelitian}

Populasi penelitian ini berjumlah 260 Mahasiswa, Jumlah Responden yang dijadikan sampel adalah 20\% dari Jumlah Populasi yaitu 52 Mahasiswa yang berasal dari Program Studi Manajemen, adapun deskripsinya sebagi berikut;

Tabel 1. Populasi Penelitian

\begin{tabular}{clc}
\hline No & \multicolumn{1}{c}{ Fakultas } & Anggota \\
\hline 1 & Keguruan dan Ilmu Pendidikan & 86 \\
\hline 2 & Ekonomi dan Bisnis & 52 \\
\hline 3 & Teknik & 64 \\
\hline 4 & Ilmu Kesehatan & 34 \\
\hline 5 & Sains dan Teknologi & 22 \\
\hline & Jumlah & 260 \\
\hline
\end{tabular}

Sumber: Data diolah Penulis

\section{Tahapan Penelitian}

Secara garis besar, tahapan-tahapan yang ditempuh dalam melaksanakan penelitian ada beberapa tahap, yaitu: Metodologi Penelitian

a. Uji Validitas dan Reabilitas

uji validitas digunakan untuk mengukur sah atau valid tidaknya suatu kuesioner. Suatu kuesioner dikatakan valid jika pertanyaan pada kuesioner mampu untuk mengungkapkan sesuatu yang akan diukur oleh kuesioner tersebut sedangkan Uji reliabilitas digunakan untuk menguji apakah alat ukur kuisioner andal sehingga informasi yang diperoleh dapat digunakan sebagai data dalam penelitian. Untuk mengukur reliabilitas dapat digunakan Rumus Alpha.

b. Uji Regresi Linier Sederhana

Regresi linier adalah regresi yang variabel bebasnya (variabel $\mathrm{X}$ ) berpangkat paling tinggi satu. Untuk regresi sederhana, yaitu regresi linier yg hanya melibatkan dua variabel (variabel $\mathrm{X}$ dan Y)

c. Uji F dan Uji T

Uji F di digunakan untuk membandingkan dua atau lebih perlakuan kelompok atau objek/data, yang masing-masing perlakuannya dilakukan ulangan. Sedangkan Uji T tujuannya untuk melihat sejauh mana pengaruh secara parsial dari variabel bebas terhadap variabel terikat

Dalam menganalisis, peneliti akan mendeskripsikan atau menggambarkan secara utuh dan nyata mengenai Pengaruh Visi Kampus dan Minat Keanggotaan Organisasi Mahasiswa kemudian data dituangkan kedalam bentuk Tabel-tabel dengan angka dan presentase untuk selanjutnya dianalisa data.

\section{Metodologi Penelitian \\ Uji Validitas dan Reabilitas}

Instrumen dengan faktor-faktor variabel yang bersangkutan. Uji coba secara empirik menggunakan korelasi produck moment dengan bantuan fasilitas komputer SPSS. 
Dasar pengambilan keputusan dalam iuji validitas adalah sebagai berikut :

1. Jika rhasil positif serta rhasil $>$ rtabel, maka butir atau variabel tersebut Valid.

2. Jika rhasil tidak positif dan $\mathbf{r h a s i l}<\mathbf{r t a b e l}$, ataupun rhasil negative $>$ rtabel maka butir atau variabel tersebut tidak valid.

Adapun rumus korelasi Product Moment untuk mencari nilai $\mathrm{r}$ hitung atau validitas sebagai berikut :

$$
r_{x y}=\frac{N \sum X Y-\left(\sum X\right)\left(\sum Y\right)}{\sqrt{\left\{N \sum X^{2}-\left(\sum X\right)^{2}\right\}\left\{N \sum Y^{2}-\left(\sum Y\right)^{2}\right\}}}
$$

Uji reliabilitas digunakan untuk menguji apakah alat ukur kuisioner andal sehingga informasi yang diperoleh dapat digunakan sebagai data dalam penelitian. Untuk mengukur reliabilitas dapat digunakan Rumus Alpha.

\section{Uji Regresi Linier Sederhana}

Regresi linier adalah regresi yang variabel bebasnya (variabel X) berpangkat paling tinggi satu. Untuk regresi sederhana, yaitu regresi linier yg hanya melibatkan dua variabel (variabel $\mathrm{X}$ dan $\mathrm{Y}$ ). Dalam menganalisis, peneliti akan mendeskripsikan atau menggambarkan secara utuh dan nyata mengenai Pengaruh Visi Kampus dan Minat Keanggotaan Organisasi Mahasiswa kemudian data dituangkan kedalam bentuk Tabel-tabel dengan angka dan presentase untuk selanjutnya dianalisa data.

\section{HASIL PENELITIAN DAN PEMBAHASAN}

Hasil perhitungan Hipotesis dengan menggunakan SPSS diperoleh koefisien diperoleh koefisien korelasi ry ${ }_{1}=0,860$. Melalui uji signifikansi dengan statistik uji $\mathrm{t}$, diperoleh $\mathrm{t}_{\text {hitung }}=1.381$. Setelah dibandingkan dengan $\mathrm{t}_{\text {tabel }}$ ternyata signifikan, $\mathrm{t}_{\text {hitung }}=1.981<\mathrm{t}_{\text {tabel }}=2,021$.

Tabel 2.

Hipotesis Pengaruh Visi Kampus terhadap Peminatan Keanggotaan Organisasi Mahasiswa.

\section{Correlations}

\begin{tabular}{|c|c|c|c|}
\hline & & Visi Kampus & $\begin{array}{c}\text { Minat Anggota } \\
\text { Organisasi Mahasiswa }\end{array}$ \\
\hline \multirow[t]{3}{*}{ Visi Kampus } & Pearson Correlation & 1 & $.860^{* *}$ \\
\hline & Sig. (2-tailed) & & .000 \\
\hline & $\mathrm{N}$ & 52 & 52 \\
\hline \multirow{3}{*}{$\begin{array}{l}\text { Minat Anggota } \\
\text { Organisasi Mahasiswa }\end{array}$} & Pearson Correlation & $.860^{* *}$ & 1 \\
\hline & Sig. (2-tailed) & .000 & \\
\hline & $\mathrm{N}$ & 52 & 52 \\
\hline
\end{tabular}

**. Correlation is significant at the 0.01 level (2-tailed).

Sumber : Data diolah Penulis

Berdasarkan Nilai Signifikansi dari tabel Output diatas diketahui nilai antara Visi Kampus (X) terhadap Minat Anggota Organisasi Kemahasiswaan (Y) adalah sebesar $0.000<0.05$, yang berarti terdapat Korelasi yang signifikan antara Variabel Visi Kampus dengan Minat Anggota Organisasi Kemahasiswaan.

Tabel 3.

Analisis Regresi Visi Kampus dan Minat Organisasi Kemahasiswaan

\begin{tabular}{lcccc}
\hline \multicolumn{4}{c}{ Model Summary } \\
\hline Model & $\mathrm{R}$ & $\mathrm{R}$ Square & Adjusted R Square & Std. Error of the Estimate \\
\hline 1 & $.860^{\mathrm{a}}$ & .739 & .734 & 3.28311 \\
\hline a. Predictors: (Constant), Visi Religius & & \\
Sumber: Data diolah Penulis
\end{tabular}


Berdasarkan Analisis Regresi table diatas, maka besarnya korelasi/Hubungan (R) yaitu sebesar 0,860 dan Koedsifisen determinasi (RSquare) sebesar 0.379 yang berarti bahwa Pengaruh Visi Kampus (X) terhadap Minat Anggota Organisasi Mahasiswa (Y) adalah 73,9\% sedangkan sisanya di pengaruhi oleh Variabel yang lain.

Tabel 4.

Uji F Regresi menggunakan analisis variansi (ANOVA)

\begin{tabular}{llccccc}
\hline \multicolumn{7}{c}{ ANOVA $^{\mathbf{b}}$} \\
Model & \multicolumn{1}{c}{ Sum of Squares } & df & Mean Square & F & Sig. \\
\hline \multirow{2}{*}{1} & Regression & 1529.061 & 1 & 1529.061 & 141.858 & $.000^{\text {a }}$ \\
\cline { 2 - 7 } & Residual & 538.939 & 50 & 10.779 & & \\
\cline { 2 - 7 } & Total & 2068.000 & 51 & & & \\
\hline
\end{tabular}

a. Predictors: (Constant), Visi Religius

b. Dependent Variable: Minat Keanggotaan Organisasi Mahasiswa

Sumber: Data diolah Penulis

Pada tabel diatas bahwa Pengaruh Visi kampus (X) terhadap Minat Anggota Organisasi Mahasiswa $(\mathrm{Y})$ dari $\mathrm{F}$ Hitung $=141.858$ dengan tingkat probabilitas $0.000<0.05$, maka model regresi bisa di pakai untuk memprediksi variabel partisipasi.

Tabel 5. Uji t

\begin{tabular}{|c|c|c|c|c|c|c|}
\hline \multicolumn{7}{|c|}{ Coefficients $^{\mathrm{a}}$} \\
\hline \multirow[t]{2}{*}{ Model } & & $\begin{array}{r}\text { Uns } \\
\mathrm{Cc} \\
\end{array}$ & $\begin{array}{l}\text { dardized } \\
\text { icients }\end{array}$ & $\begin{array}{c}\text { Standardized } \\
\text { Coefficients }\end{array}$ & \multirow[t]{2}{*}{$\mathrm{t}$} & \multirow[t]{2}{*}{ Sig. } \\
\hline & & $\mathrm{B}$ & Std. Error & Beta & & \\
\hline \multirow[t]{2}{*}{1} & (Constant) & 3.889 & 2.817 & & 1.381 & .174 \\
\hline & Visi Kampus & .892 & .075 & .860 & 11.910 & .000 \\
\hline
\end{tabular}

Sumber: Data diolah Penulis

Persamaan Regresinya dapat di tulis sebagi berikut :

$$
\begin{aligned}
& Y=a+b X \\
& Y=a+B x \text { atau } 3.889+0.892 X
\end{aligned}
$$

Bahwa terdapat korelasi positif dan signifikan antara Visi Kampus dengan Peminatan Keanggotaan Organisasi Mahasiswa. Dalam statistik, berdasarkan uji koefisien determinasi, hasil penelitian ini menggambarkan bahwa sebanyak 89.2\% varians skor Minat Anggota Organisasi Mahasiswa dipengaruhi oleh faktor Visi Kampus. Kontribusi sebesar itu jelas tidak bisa diabaikan. Dengan kata lain, dapat ditafsirkan bahwa dengan Visi Kampus, maka Peminatan Keanggotaan Organisasi Mahasiswa akan baik. Persamaan regresi yang dihasilkan untuk menerangkan Visi kampus dengan Peminatan Keanggotaan Organisasi Mahasiswa adalah y $=3.889+.892$ X, artinya setiap kenaikan satu satuan variabel Visi Kampus (X) akan meningkatkan variabel Peminatan Keanggotaan Organisasi Mahasiswa (Y) sebesar .892 pada konstanta 3.889.

\section{KESIMPULAN}

Berdasarkan hasil penelitian dan pembahasan mengenai pengaruh visi kampus terhadap minat keangotaan organisasi mahasiswa, maka dapat disimpulkan bahwa visi kampus bisa memberikan pengaruh positif terhadap minat keanggotaan organisasi mahasiswa sebesar $89.2 \%$, visi kampus yang sesuai dengan semgantt ataupun cita cita mahasiswa akan memberikan energy yang positif, terutama bagi mahasiswa yang fokus mendalami Ilmu agama di samping keilmuan yang sediakan oleh program studi kampus, oleh karena itu mahasiswa merasa yakin bahwa visi kampus akan memberikan peluang pada mahasiswa untuk berkembang semakin berkembang.

\section{SARAN:}

Penelitian Selanjutnya diharapkan lebih memperhatikan metode pengumpulan data yang lebih mendalam, di samping menggunakan kuesioner juga di harapkan juga menggunakan teknik wawancara 
sehingga informasi yang digali bisa lebih banyak dan mendalam, dan pihak kampus lebih memfasilitasi kegiataan kemahasiswaan yang tujuannya untuk menwujudkan visi misa kampus dan peneliti selanjutnya diharapkan lebih menyempurnakan lagi beberapa kelemahan dalam penelitian ini. Kelemahan tersebut antara lain dalam mendeskripsikan hasil penelitian serta keterbatasan kemampuan dalam membuat dan mengolah instrument, atau dalam perluasan populasi agar hasil penelitian yang dilakukan akan semakin baik lagi, dan sebaiknya mencari faktor faktor lain yang bisa memberikan pengaruh yang dari sudut pandang lain.

\section{REFERENSI}

Basri. (2020). Peran Ormawa dalam Membentuk Nilai-nilai Karakter di Dunia Industri (Studi Organisasi Kemahasiswaan di Politeknik Negeri Balikpapan). Al-Adabiya: Jurnal Kebudayaan Dan Keagamaan, 15(01), 139-160. https://doi.org/10.37680/adabiya.v15i01.273

Mulyanto, Heru dan Wulandari, Anna. (2010). Penelitian : Metode dan Analisis. In CV. Agung Semarang.

Maulana, Indra. (2010). "Hubungan Kepemimpinan Transformasional dengan Kinerja Pengurus Lembaga Dakwah Kampus UIN Syarif Hidayatullah Jakarta.

Kailani, Najib. (2011). Kepanikan Moral dan Dakwah Islam Populer (Membaca Fenomena 'Rohis' di Indonesia). Analisis: Jurnal Studi Keislaman, 11(1), 1-16. https://doi.org/10.42042/ANALISIS.V11I1.604

Ukbah, Muhammad. (2013). Peran Lembaga Dakwah Kampus Al-Jami dalam Meningkatkan Komunikasi Dakwah Mahasiswa UIN Alaudin Makassar. https://doi.org/10.1017/CBO9781107415324.004

Oviyanti, Fitri. (2016). Kata Kunci: Journal of Islamic Education Management, 2(1), 61-79.

Putri, QQ Presika Jati. (2017). Pengaruh Pemakaian Hijab Syar'i terhadap Interaksi dengan Lawan Jenis.

Riono, Slamet Bambang; Muhammad Syaifulloh; Suci Nur Utami. (2020). Pengaruh Komunikasi Organisasi, Budaya Organisasi, dan Komitmen Organisasi terhadap Kinerja Pegawai di Rumah Sakit dr. Soeselo Kabupaten Tegal. Syntax Idea, 2(4), 138-147. https://doi.org/https://doi.org/10.36418/syntax-idea.v2i4.190

Pelupessy, Nur Khozin Abdullah dan Husein,Saddam. (2018). Pembinaan Akhlak Mulia Mahasiswa Dalam Lembaga Dakwah Kampus (Ldk) Al-Izzah Iain Ambon. Al-Iltizam: Jurnal Pendidikan Agama Islam, 3(1), 53. https://doi.org/10.33477/alt.v3i1.417

Setiawan, Asep Iwan. (2011). Efektivitas Dakwah Fiah: Studi Model Dakwah pada Lembaga Dakwah Kampus. Jurnal Ilmu Dakwah, 5(2), 541-574.

Fatimah, Siti. (2014). Mentoring terhadap Kedisiplinan Beribadah Mahasiswa Lembaga Dakwah Kampus ( LDK) Darul Amal STAIN Salatiga.

Aisyah, Siti. (2015). Peranan Lembaga Dakwah Kampus dalam Meningkatkan Komunikasi Dakwah Mahasiswa Universitas Islam Negeri Alaudin Makassar. Jurnal Al-Khitabah, II(1), 71-82.

Suasana, I. Gusti Agung Ketut Gede, Suarjaya, Anak Agung Gede, \& Dana, I. Made. (2019). Pengembangan Kinerja Organisasi: Menggali Minat Untuk Menjadi Anggota Koperasi Mahasiswa Di Universitas Udayana Bali. INOBIS: Jurnal Inovasi Bisnis Dan Manajemen Indonesia, 2(2), 299-314. https://doi.org/10.31842/jurnal-inobis.v2i2.92

Syaifulloh, Muhammad. (2017). Peranan Dosen Tanpa Jabatan Fungsional terhadap Pengembangan Kreatifitas Mahasiswa di Universitas Muhadi Setiabudi. Prosiding Seminar Nasional Publikasi Hasil-Hasil Penelitian Dan Pengabdian Masyarakat "Implementasi Penelitian Dan Pengabdian Masyarakat Untuk Peningkatan Kekayaan Intelektual" Universitas Muhammadiyah Semarang, 30 September 2017, (September), 246-251.

Syaifulloh, Muhammad, Wahid, Farhan Saefudin \& Nasiruddin, Nasiruddin. (2018). Analisis Produktivitas Kegiatan Penelitian Dosen di Universitas Muhadi Setiabudi. JBIMA (Jurnal Bisnis Dan Manajemen), 6(2), 154-162.

UU No. 20. (2003). Undang-Undang Republik Indonesia Nomor 20 Tahun 2003 tentang Sistem Pendidikan Nasional. 